\title{
Here I go again
}

\section{Ben Thair-O'Reidy}

The light is dimmed by piles of paper. Floorboards groan under the pressure of fat, sweaty bodies. Reception staff scream as strips are torn off them. Just when you thought it couldn't get worse, award-wanting directors Cameron and Clegg bring you a story of power, greed and sex (safer hopefully!). A tale bursting with twists and turn-arounds the like of which haven't been seen for over 10 years. Coming to a clinic near you: 'Fund-holding II - Commissioning Consortia'.

So, fund-holding is back - whoopee! Been there, done that, bought the swimming, sorry, patient rehab hydrotherapy pool with the massive savings we made before the scheme was pulled from under us, as most general practice successes are. But in the words of Whitesnake, in number 5 spot in the 'songs in my head' chart this week: 'Here I Go Again!'.

Oh I can hardly contain myself - in fact, in the number 4 spot this week in my head chart it's the Pointer Sisters with 'I'm So Excited!'. It's going to be so much fun, just like Dragon's Den as providers stand (or kneel if I get my way) surgical cap in hand with their ideas basically wanting a stack of cash to provide them. Well, yes, Mr Hospital Trust, you can have $£ 100000$ but for this I want patients to be able to walk out of hospital when discharged, not carried out so they immediately score you another 'ker-ching' re-admission fee before actually leaving the building; any acquired hospital infection will trigger a $10 \%$ discount on a patient's treatment costs; if any investigations already performed by the patient's GP are repeated, you'll refund the cost; and no more offering patients appointments at times when they've said they're going to be away - OK?

Now, where's the pharmacy adviser's number? Let's see the look on their face now the tables are turned. Yes, it is quite an expensive drug isn't it, and yes there is a cheaper version. But you see, as I've tried to make you understand many times before, the cheaper version just doesn't work

J Fam Plann Reprod Health Care 2010; 36(4): 256

Makemrich Surgery, Stack-up-Dosh, UK

Ben Thair-O'Reidy, MRCGP, General Practitioner does it? So, I think we'll go with the more costly drug, which will in essence save us money in the long term. Do close the door on your way out, won't you?

One thing we'll need to change though is the rules about what savings can be used for. No, I'm not talking about adding Mercedes and BMWs to the list of approved patientbeneficial items. I'm talking about the previous nonsense that prevented us - in our patch anyway - from using savings to employ a doctor whilst allowing us to employ a candleabusing therapist, or have a water cooler in the waiting room. Moreover, we don't want any of this ridiculous, and childish, "I'm spending the money so you can't take it off me" behaviour that resulted in the ratio of practice ECG machines to doctors being in the region of 2 to 1 .

I'd almost forgotten the fun we'll have with our hospital colleagues when they have to come to our practice to run an outpatient clinic. They'll get a crash course in what general practice does - to make up for the fact that they didn't bother attending their student GP placement - and let's see how they like having to pay to park. So, in at number 3 this week, Madness with 'House of Fun'.

Once and for all we'll be able to put an end to this drive to make GPs take on the provision of sexual health services. There's only one place these should be and that's in a properly staffed and equipped GUM clinic as the Take That hit 'Ain't No Sense in Love' emphasises with its lyric "Oh, this misery. There's no place on earth I'd rather be" - in at number 2 this week.

Why am I so excited about this latest development in health services in the UK? Because I've been through it before so know how to make it work, for everybody's benefit. It's the same old story re-named, like many movies. Bad guy dumps on good guy, placing good guy in seemingly impossible position and making survival unlikely. But good guy finds weakness in bad guys' plans, turns things around, saves the day and lives happily ever after.

The End.

Roll credits to song in the number 1 spot this week which, if history is anything to go by, will be there for a while yet: Bryan Adams singing 'Everything I Do', I do for ... my patients, obviously.

\section{MEETINGS AND COURSES}

\section{Annual Courses}

Title: Courses in Sexual and Reproductive Health organised by The Margaret Pyke

Trust. Details: See display advertisement on inside back cover.

\section{Academic Year 2010/2011}

Title: Training in Psychosexual Medicine. Venue: Locations throughout the UK. Details: Balint-type seminars for doctors. Basic and advanced level groups with experienced leaders. leading to Diploma, and Membership of the IPM. 1-day stand-alone Course: Autumn Clinical Meeting to be held in London on Saturday 6 November 2010. Accreditation: Accredited training for FSRH Sexual Problems Certificate. Information: Administrative Secretary, Institute of Psychosexual Medicine (IPM), 12 Chandos Street, Cavendish Square, London W1G 9DR, UK. Tel: +44 (0) 207580 0631. E-mail: admin@ipm.org.uk.Website: ipm.org.uk.

29 October 2010

Title: Public Health \& Sexual and Reproductive Health Training Day. Venue:
Royal College of Obstetricians and Gynaecologists, London, UK. Details: Faculty website at www.frsh.org (Courses \& Meetings).

\section{November 2010}

Title: Course of 5. Venue: The Barns Hotel, Cock Sparrow Lane, Cannock, Staffordshire WS12 4PB, UK. Details: Cost £350 (incl. VAT), including refreshments and lunch. Accreditation: FSRH. Information: Training Department, South Staffs PCT, Edric House, Wolseley Court, Rugeley WS15 1UW, UK. Tel: to book call Sonia Cooper on +44 (0)1889 571456; enquiries to Dr Kundu on $+44 \quad(0) 7803$ 668023. E-mail: C.A.S.H.Training@southstaffspct.nhs.uk.

\section{8-19 November 2010}

Title: FSRH Current Choices Conference. Details: See display advertisement on inside back cover.

21 January 2011

Title: Joint BASHH and FSRH Meeting. Venue: Royal Society of Medicine, London, UK. Details: Faculty website at www.frsh.org (Courses \& Meetings).
11 April 2011

Title: "Hot, Cold and Painful Sex in Women" an Imperial College Masterclass. Venue: 20 Eastbourne Terrace, London W2 6LG, UK. Details: A day focused on the aetiology and management of genital pain, vaginismus and low desire. Accreditation: Royal College of Physicians applied for. Information: Dr David Goldmeier, The Jefferiss Wing, St Mary's Hospital, Praed Street, London W2 1NY, UK. Tel: +44 (0) 207886 6622. Fax: +44 (0) 2078866618 E-mail: David.Goldmeier@imperial.nhs.uk.

There is a charge of $£ 65.00+$ VAT for each meeting/course publicised in this section of the Journal. For guaranteed inclusion in the January 2011 issue all course details should be with Sarah Monger by 19 November 2010. For a booking form please contact Sarah Monger. Mobile: +44 (0) 7866 523300. E-mail: sarah.monger@me.com. 